
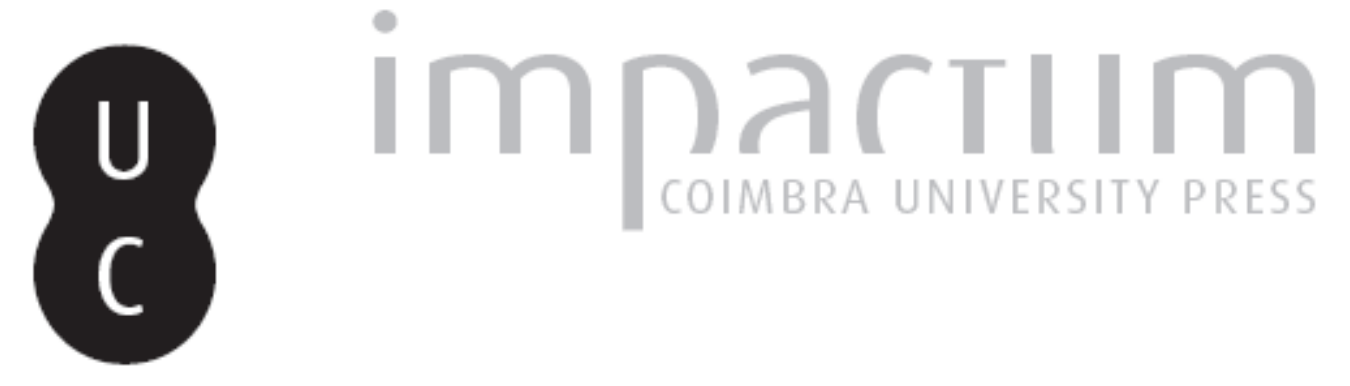

\title{
Três nobres vectores da utopia sergiana
}

Autor(es): Barros, Henrique de

Publicado por: Imprensa da Universidade de Coimbra

URL persistente:

URI:http://hdl.handle.net/10316.2/45050

DOI: $\quad$ DOI:https://doi.org/10.14195/2183-8925_5-1_11

Accessed : $\quad$ 26-Apr-2023 12:11:23

A navegação consulta e descarregamento dos títulos inseridos nas Bibliotecas Digitais UC Digitalis, UC Pombalina e UC Impactum, pressupõem a aceitação plena e sem reservas dos Termos e Condições de Uso destas Bibliotecas Digitais, disponíveis em https://digitalis.uc.pt/pt-pt/termos.

Conforme exposto nos referidos Termos e Condições de Uso, o descarregamento de títulos de acesso restrito requer uma licença válida de autorização devendo o utilizador aceder ao(s) documento(s) a partir de um endereço de IP da instituição detentora da supramencionada licença.

Ao utilizador é apenas permitido o descarregamento para uso pessoal, pelo que o emprego do(s) título(s) descarregado(s) para outro fim, designadamente comercial, carece de autorização do respetivo autor ou editor da obra.

Na medida em que todas as obras da UC Digitalis se encontram protegidas pelo Código do Direito de Autor e Direitos Conexos e demais legislação aplicável, toda a cópia, parcial ou total, deste documento, nos casos em que é legalmente admitida, deverá conter ou fazer-se acompanhar por este aviso.

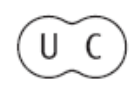




\section{REVISTA DE HISTÓRIA DAS IDEIAS 5}

\section{António Sérgio}

*

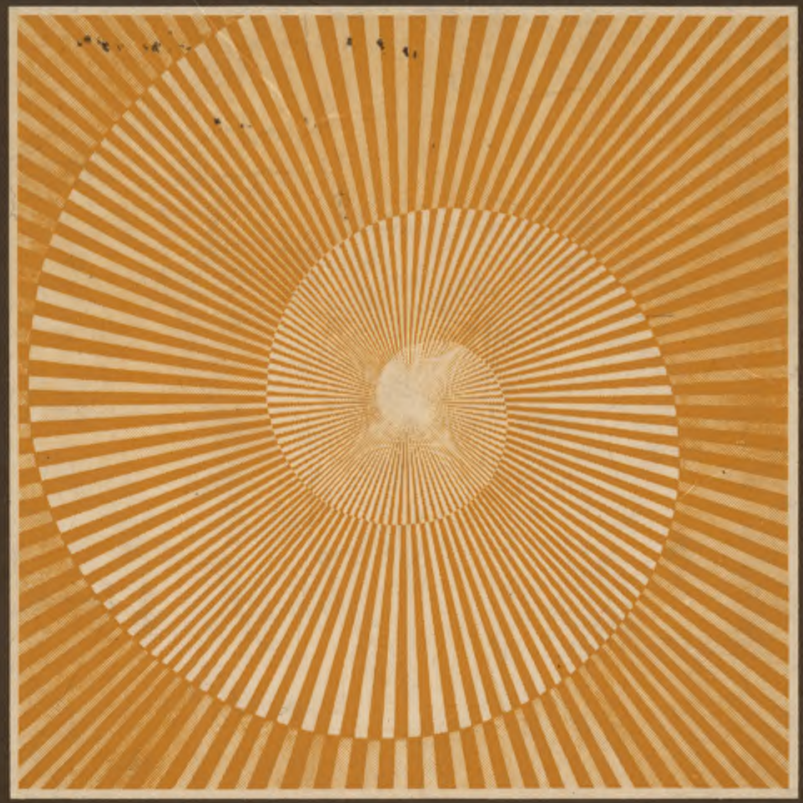

INSTITUTO DE HISTÓRIA E TEORIA DAS IDEIAS FACULDADE DE LETRAS 


\title{
TRÊS NOBRES VECTORES DA UTOPIA SERGIANA* **
}

Escusado seria talvez informar os leitores - mas não deixarei de o fazer, insistindo numa opinião que já por várias vezes defendi, aliás na esteira de outros e mais autorizados escritores - que, para mim como certamente para eles, a palavra utopia não encerra o menor conteúdo depreciativo e muito menos pejorativo. Julgo-a, bem pelo contrário, portadora da mais bela mensagem que um homem pode transmitir aos seus congéneres, coevos e futuros: a esperança num porvir criador, a promessa de dias mais plenos de vida, de acções morais e cívicas mais dignas, de realizações culturais mais enriquecedoras da personalidade.

Não confundo, em suma, jamais admiti confundir, a austera utopia com a frívola quimera. Li algures, e já o tenho repetidamente citado, que utopia não traduz o irrealizável, corresponde, sim, ao irrealizado, e estou em crer que se trata de uma distinção deveras esclarecedora na sua singela limde Lisboa.

* Instituto Superior de Agronomia da Universidade Técnica

\begin{abstract}
Assume este escrito, como a certa altura nele se diz e o leitor imediatamente verá, carácter apenas memorialista, baseia-se somente em recordações pessoais (bem vivas, aliás!), não procurou intencionalmente qualquer apoio documental ou bibliográfico. Animado, porém, pelo interesse que o tema em mim próprio despertou, resolvi continuar a pensar nele, a estudá-lo melhor, a desenvolvê-lo e aprofundá-lo, resolução de que proveio ter conseguido redigir, em colaboração com Fernando Ferreira da Costa, um volume de cento e tal páginas que se chamará provavelmente "António Sérgio, criador de nobres utopias» e esperamos que seja em breve publicado. Os leitores deste artigo, e daquele que Ferreira da Costa aqui apresenta também, se lerem esse nosso livro, não deverão pois estranhar encontrar entre eles semelhanças, coincidências e até repetições.
\end{abstract}


pidez. A quimera, bem diversamente, é invenção de cérebros sem a mínima noção do concreto, sem amarras na realidade, sem projecção no futuro, libertos de toda a sujeição ao risco que o homem menos pode evitar, o erro; é mesmo por menosprezar completamente os perigos do erro que, de um ponto de vista humano, a quimera acaba por ser produto mental sem direito a absolvição social.

Ao falar, portanto, de António Sérgio como utopista, ao escrever que existiu entre nós e porventura subsiste uma utopia de raiz sergiana, não estou de modo algum a enfileirar entre os detractores, raros aliás, hoje em dia, de uma figura intelectual e cívica que todos nós, portugueses, e sobretudo os democratas, devemos venerar, até porque foi ela quem mais e melhor nos ensinou a manter acesa a chama de um espírito crítico não negativista, posição bem pouco frequente nesta nossa terra. Estou, pelo contrário, a tentar juntar a minha voz modesta às daqueles que, tendo ou não conhecido Sérgio em vida e com ele privado, procuram hoje estudar e revelar as suas pessoa e obras, de modo a que, de uma vez por todas, se faça a justiça de as colocar no estreito andar da pirâmide cultural portuguesa, ao lado e a par de umas exíguas dezenas de lídimos pensadores lusos comprovadamente capazes de terem semeado ou semearem ideias aptas a medrar no solo pátrio ou alheio.

Os meus contactos pessoais com António Sérgio - que, aliás, só comecei a visitar depois de ter ele regressado do seu exílio em Paris - passaram a ser tão frequentes, até à doença que o levou a não querer mais sair de casa e a evitar encontros pessoais, que se podiam dizer assíduos. Não me atrevo, porém, de modo algum, a afirmar que tivessem sido íntimos: nem a diferença de idades o propiciava (Sérgio era apenas dois anos mais novo que meu Pai, João de Barros), nem a discrepância de temperamentos o facilitava, o dele, embora sempre acolhedor e ate hospitaleiro, um tanto frio, ascético, reservado, o meu, sobretudo então, sentimental, tímido e tendencialmente respeitador dos homens célebres.

Já que veio a propósito lembrar meu Pai, o que faço sempre que uma ocasião se me oferece porque considero mais esquecido do que mereceria estar, nesta renovada Democracia, ainda à procura do seu melhor caminho, o nome desse grande cantor das melhores virtudes humanas do nosso Povo, recordando ter sido ele quem me apresentou a Sérgio na estação do Rossio onde se reunira um punhado de republicanos inconformados e intrépidos para deste se despedirem à partida para o exílio forçado, ja que me referi a João de Barros, ia dizendo, consinta-se-me que tente uma rápida com- 


\section{Utopia Sergiana}

paração entre duas figuras que admiro com igual sinceridade, a segunda obviamente com particular devoção, embora as saiba diferentes, não direi em tudo e por tudo, mas seguramente em muito e por muito, excepto na luminosidade da inteligência, na solidez da cultura, na rijeza do carácter e na lhaneza do trato. António Sérgio, que todos sabemos ter sido um prosador excelso, poeta foi também, e isto pouca gente o saberá hoje: poeta de inspiração austera, abstracta e racionalizante, mas de inegável talento. Em muito e por muito diferentes, como artistas da palavra escrita, em verso ou prosa, eram com efeito os dois grandes portugueses, já que a secura por assim dizer geométrica da rara poesia conhecida de Sérgio, expoente da razão pura e do aceso espírito crítico, contrastava visivelmente com a intuição vitalista do João de Barros poeta, voltado para a celebração do belo, para a exaltação do homem, para o amor feminino, para os encantos da natureza, para as obscuras lutas quotidianas do povo. Se a poesia de João de Barros ainda não estará, apesar do que já afirmei, de todo esquecida, da de António Sérgio (que, aliás, como poeta jamais se reconheceu) raros hoje ou nenhuns se lembrarão, mas é lastimável que assim aconteça porque ela apelava, com exemplar sobriedade estética, para valores imateriais, ligados à essência do que é mais racional na mente do homem, alheios ao sentimentalismo mas não a tudo o que é intelectualmente estimulante.

Seria, na verdade, quere-me parecer, um curioso estudo a realizar (evidentemente por competente crítico literário, profundo conhecedor das duas obras), este de estabelecer um confronto entre os dois escritores da mesma geração, com tantas afinidades ideológicas mas tão diferenciados pendores literários. Como exemplo típico da flagrante distinção das sensibilidades artísticas deles, poderá recordar-se o que cada um pensava de Guerra Junqueiro, ambos sem lhe contestar o génio: Sérgio, implacável e pertinaz censor da grandiloquente retórica junqueiriana, João de Barros incansável admirador daquele poeta de raiz, tão capaz de exaltar o sublime em rimas tonitruantes como de celebrar em versos serenamente cristalinos a beleza singela da natureza, da mulher, dos melhores sentimentos humanos.

Não é este, porém, o meu tema de hoje, que de resto estaria fora do meu alcance abordar completamente, e vai sendo tempo de tratar, aliás apenas exemplificadamente, das tais «nobres utopias sergianas», sempre colocadas entre a quimera e a realidade.

Vou referir-me, claro está, às utopias do homem público, do doutrinador social, do pedagogo da política: jamais 
ousaria mencionar, se é que as houve ou há, as utopias do pensador puro, do filósofo em suma; seria indesculpável atrevimento, procurar penetrar, armado apenas com a minha «plebleia tecnologia», no edifício imponente das «aristocráticas humanidades».

A primeira utopia sergiana de que me proponho tratar aqui, cujo teor conservo bem presente por ter visto o seu autor expô-la repetidamente pela palavra e pela escrita, chamar-lhe-ei a crença na abundância ou, para me exprimir mais completamente, a crença na viabilidade tecnológica da abundância produtiva.

Sérgio formara a convicção firme de que, tecnologicamente, o homem já aprendera o bastante para se encontrar apto a «vencer a raridade» e poderia, consequentemente, exercer sobre a natureza comando suficiente para extrair da terra tudo quanto era essencial à vida de todos e cada um em bens e comodidades materiais. Muito bem sabia ele, evidentemente, pensador tão lúcido como culto, e homem generoso, que semelhante abundância, embora na sua opinião tecnicamente desde já viável, não era ainda uma realidade à escala universal, como o não era à escala nacional: se a abundância, como era bem patente, não chegara às casas de todos os homens, se nem sequer franqueara a porta da maioria delas, não era porém devido à incapacidade da tecnologia, pensava ele, era somente porque uma defeituosa organização social, fruto da rapacidade de poucos, da indiferente passividade de muitos e da humildade de quase todos, a mantinha retida num esquema de repartição do produto nacional caracterizado pelo desequilíbrio iníquo, dominado pelo egoísmo, surdo aos clamores da justiça.

Estudos, investigações e observações que Sérgio não chegou a conhecer (alheado como resolveu passar a estar, sem ter perdido a sua inteligência, do fluir do pensamento novo a partir dos fins dos anos 50), vieram revelar que a abundância produtiva (neste mundo finito a sob repovoar-se com rapidez), entendida no sentido de a todos poderem chegar quinhões de riqueza iguais ou próximos dos valores médios alcançados nos actuals países prósperos (isto é, com dietas alimentares variadas e ricas em proteína animal, habitação condigna e comodidades domésticas, educação conveniente, segurança apropriada e fartura de bens e serviços supérfluos), constituía uma pretensão que já passara da fase da utopia para penetrar na da quimera. O problema hoje dominante, e porventura o mais angustioso, dos tempos difí- 
ceis, incertos e ameaçadores que estamos vivendo, admitindo que acabará por se conseguir evitar o holocausto atómico, é o que diz respeito às consequências do esgotamento dos recursos naturais não-renováveis (alguns, e dos mais indispensáveis à manutenção do estilo de vida que inventámos e a que nos habituámos, com a exaustão já à vista, raros ou mesmo nenhum previstos para durar muito para além do ano 2000) e da dificuldade crescente de gerir, a escala planetária, os recursos naturais renováveis, com a prudência e a sabedoria necessárias para impedir que, ao serem deterioradas grave ou mesmo irreversivelmente, por erros cometidos no respectivo manejo, inconsciente ou mesmo conscientemente, as fontes de onde continuamente emanam estas acabem por secar passando assim tais recursos a ser também não-renováveis.

Pois bem, tanto quanto consigo lembrar-me, esse problema dominador, aqui apenas esboçado e à análise de cujas temerosas implicações nenhum intelectual honrado logra hoje furtar-se (em especial, após o alarme mundialmente repercutido que foi o famoso "Relatório do M.I.T.», a que se tem seguido caudalosa literatura, que chega ao ponto de ter deixado de ser heresia económica advogar o «crescimento zero»), jamais parece ter impressionado a mente de Sérgio, pelo menos com a força suficiente para a levar a duvidar de que a equidade repartidora, aliás tão indispensável então como hoje, sendo condição necessária, não era condição bastante para eliminar as carências prementes com que se debate uma humanidade que não consegue suster nem o seu aumento nem as suas ambições. O ímpeto cada vez mais forte com que a Ecologia, essa nova ciência pluridisciplinar e confluente, vai abrindo caminho e conquistando lugar próprio no âmbito da Ciência, dando origem a uma reflexão profunda no sentido de coordenar o bio-físico com o social, de compatibilizar as ciências da natureza com as do homem, de analisar o relacionamento de causalidade circular entre o ser humano e o ambiente que o mantém vivo, ainda mal se encontrava à vista dos homens de pensamento; não é, portanto, certamente de estranhar e muito menos de censurar que Sérgio, conquanto ávido leitor das «novidades intelectuais», não se tivesse antecipado a hipóteses, observações e conclusões que só umas duas dezenas de anos mais tarde, após portanto a sua retirada da vida intelectual criadora, a todos acabariam por se impor tão sólidas são as provas e as análises em que se alicerçam.

Tal era, porém, o calor persuasivo com que explicava aos seus contemporâneos, e em particular aos jovens dos anos 30 a 50, que a ciência e as múltiplas tecnologias dela derivadas já haviam avançado o bastante para ter tomado a abun- 
dância produtiva tecnicamente realizável a nível mundial e que, se ela ainda não estava visível ao nível do consumo senão em raros países ricos (os tais que formam a «sociedade da abundância», tão penetrantemente estudada por Galbraith), e de modo algum à superfície de todo o planeta, antes exibia a sua desoladora ausência na maioria dos lares, era tão somente porque havia homens que assim expandida a não desejavam e ocupavam posições de mando e influência que lhes permitiam impedi-la, - tal era, ia dizendo, o calor persuasivo de Sérgio que o seu apostolado de «crente na viabilidade da abundância» deve realmente ser considerado o primeiro dos três vectores (nobres, persisto em dizê-lo) da utopia sergiana, tema desta pequena tentativa de ensaio. Já nessa época, nós outros, os homens de formação tecnológica que com ele mais privávamos - à testa deles, sem a menor dúvida, Mário d'Azevedo Gomes - não deixávamos de o advertir que a natureza não era assim tão fácil de domar como ele mostrava supor, e que a técnica se encontrava ainda bem longe de permitir, sem perigosas intervenções destabilizadoras dos sempre precários equilíbrios dinâmicos dos sistemas ecológicos, a produção de bens e serviços que bastassem para a todos garantir vida ao abrigo da penúria, da ignorância e do medo. Ele, porém, mostrava-se confiante, não se deixava alarmar pelos avisos que já então iam aparecendo de certas acções humanas constituírem ameaças sérias à estabilidade do potencial produtivo, pensava convictamente que a transformação social repartidora pela qual se batia e que (para ele como para muitos de nós) deveria assumir o mais acentuado cariz cooperativista, encheria um dia todas as bolsas pelo menos com tudo aquilo de que o homem carece para se sentir cidadão.

Seja como for, a questão está hoje levantada pelos cientistas e por divulgadores de talento, bem à vista de todos nós minimamente informados, e não penso que, entre os que são sinceros, sejam muitos os que ignoram que só a mais sapiente, cuidadosa e honesta, e portanto a mais socialista, gestão internacional dos recursos naturais (renováveis e não-renováveis), salvará o homem da prisão em que o encerra aquele dilema que René Dumont, tão fortemente, sintetizou ao exclamar que a escolha contemporânea imposta à humanidade se fará entre «a utopia ou a morte!». Semelhante gestão de recursos, ineficiente sem uma vasta concertação internacional, posta ao abrigo das cobiças depredadoras de homens sem capacidade altruísta, servida por avanços científico-tecnológicos que de momento já começamos a poder entrever, nos domínios da captação de novas energias renováveis, a come- 


\section{Utopia Sergiana}

çar pela directa da radiação solar, da intensificação da produção de alimentos liberta das desregradoras influências climáticas, da obtenção de proteínas com novas proveniências, da captação de elementos minerais nos fundos marítimos e nos espaços sidéreos, etc., talvez permita que chegue o dia em que se consiga evitar que esta persistente visão sergiana, utópica como era, se transforme em quimera aniquiladora da humanidade, em vez de se aproximar, pelo contrário, de uma realidade prometedora. Seja como for, e dados os desmandos cometidos pelo homem na maneira como lida com os recursos naturais, sem procurar defendê-los nem sabendo como geri-los com os olhos bem postos no futuro, pode ter-se como infelizmente certo que a «era da abundância» não está no nosso horizonte, e que existem até, inversamente, sérias razões para temer que o esteja antes uma «era de penúria generalizada».

A segunda utopia sergiana, que ele próprio aliás (na sua última fase de militante cooperativista) soube fazer aproximar da realidade social, afastando-a consequentemente da quimera, foi aquela a que poderão dar-se os nomes de «república cooperativa», «ordem cooperativa», «cooperativização integral», «pan-cooperativismo» e porventura outras mais, todas ambicionando significar que não se trata nem de capitalismo nem de socialismo marxista, mas sim de algo diferente e original. Charles Gide, economista de grande renome no seu tempo, figura patriarcal de pensador na doutrinação cooperativa, em seguimento das ideias lançadas pela chamada «Escola de Nîmes», de que fora um dos fundadores, imaginou que a «ordem cooperativa» se iria estabelecendo gradualmente, país por país, e finalmente em todo o Mundo, mediante a progressiva expansão de um movimento cooperativo unificado e unificador: começar-se-ia pelas cooperativas locais de consumo, as mais susceptíveis de acatamento integral dos universais «princípios cooperativos» (mais tarde codificados pela «Aliança Cooperativa Internacional»), aquelas formariam as suas uniões, em escalões sucessivos, as quais, para conseguirem abastecer-se sem terem que recorrer a intermediários privados lucrativistas, criariam elas próprias indústrias produtoras dos bens e serviços que se propunham fornecer aos consumidores e, por último, se dedicariam à produção agro-pecuária e florestal para obterem matérias-primas para tais indústrias ou bens de consumo directo. Trata-se da outrora muito citada, embora hoje de todo abandonada pelos propug- 


\section{Antonio Sérgio}

nadores do cooperativismo, antevisão gideana da edificação pelos consumidores organizados de um «país cooperativo», em quatro fases: duas comerciais (a retalho e por grosso), uma industrial, uma agrícola.

Sérgio, durante a sua estadia em França, conheceu e estudou a obra inicial de Charles Gide e as propostas da «Escola de Nîmes», e regressou à Pátria disposto a divulgar entre nós a ideia da "republica cooperativa», dessa nova estruturação social não violenta e respeitadora das liberdades públicas, julgada capaz de evitar a revolução social à maneira soviética, ao mesmo tempo que se propunha abolir a motivação das decisões económicas pela intenção de maximizar o lucro privado. Não, evidentemente, que pensasse, como ouvi acusá-lo um dia, com pesada ironia, um intelectual mal intencionado e de vistas curtas, substituir o governo da Nação por um «grande armazém central grossista», mas o certo é que a sua proposta surgia como irrealizável aos olhos dos que conheciam de perto a realidade social e económica. Disto mesmo, aliás, já então se apercebera o próprio Charles Gide, posto em face de uma outra concepção reformadora igualmente generosa, apresentada (também em França) por George Fauquet: a do sector cooperativo, a formar pela livre associação das cooperativas de todos os tipos, desde as de consumidores até às de produtores, procurando sempre expandir-se, mas disposto a conviver, concorrenciando-os lealmente na medida do necessário e do possível, com os outros dois grandes sectores da actividade económica de uma sociedade democrática, que são o sector privado e o sector público.

À ideia de um «sector cooperativo», a alargar-se sucessivamente até onde lhe fosse possível chegar, tendo como limite teórico, sem prazo fixado, a "república cooperativa», acabaria António Sérgio por aderir, quando colocado em frente dos problemas concretos do movimento cooperativo português, particularmente da cooperação agrícola, com a sua tão característica especificidade, para a qual insistentemente fui chamando a sua atenção, com argumentação pragmática que ele acabou por aceitar de boa mente. Fernando Ferreira da Costa tem dito e escrito diversas vezes que foi por influência minha que Sérgio trocou a «utopia maior» do pan-cooperativismo pela «utopia menor» do sector cooperativo. Não sei até que ponto é exacta esta informação, da qual nunca me vangloriei nem vangloriarei, mas sei que, no belo Prefácio que escreveu para a obra colectiva Cooperativismo. Objectivos e modalidades, em que também colaborei encarregando-me da cooperação agrícola, Sérgio defendeu a ideia do sector cooperativo, com muita convicçãoo senão verdadeiro entusiasmo. Tal era, 
porém, o seu visceral pendor para a utopia que, mesmo depois desta inflexão de rumo, aquilo que ele configurava seria um sector fechado, "onde pudesse viver em regime socialista um indivíduo que o quisesse, apesar de não serem socialistas o país e o Estado de que esse país é cidadão». Ora, o conceito moderno e realista do "sector cooperativo», aquele a que pessoalmente adiro e que a nossa Constituição perfilhou, é o de um sector aberto ao exterior, disposto sem dúvida a expandir-se, obviamente à custa dos restantes, mas em competição com eles, numa atitude de constante inter-relacionamento, e sem pretender forçar o cooperador a fazer toda a sua vida económica e cultural encerrado no sector cooperativo. No pouco que Sérgio deixou escrito sobre o sector cooperativo (o Prefácio acima referido foi o último texto que escreveu), aparentemente abandonado que fora por ele o grande ideal do «pan-cooperativismo», permaneceram, em suma e a meu ver, resquícios de utopia.

Seja como for, ao entrar com plena lealdade na batalha pela expansão e fortalecimento do sector cooperativo, que veio a ser a adoptada constitucionalmente entre nós, embora sob forma algo fruste, Sérgio deu provas da sua capacidade para adaptar a sua utopia às realidades da terra onde vivia e ardentemente desejava servir.

E, já agora, como apontamento final sobre o Sérgio cooperativista, já que mais não posso agora escrever entre o muito que me ocorre ou ocorreria, referirei aqui, com natural emotividade, a opinião que da sua própria boca ouvi, quando já patenteava total descrença na sua obra sem par de criador de cultura, no sentido de só considerar válida e única batalha não perdida a sua pertinaz e sempre abnegada luta pela causa do cooperativismo em Portugal. Isto mesmo me declarou ele um dia, em visita que lhe fiz quando, já obstinadamente recluso na sua casa da Travessa do Moinho de Vento, à Lapa, afirmando do mesmo passo, aliás com serenidade, pelo menos aparente, a inutilidade da sua obra, rara entre nós, de filósofo, pedagogo, ensaísta, doutrinador político, agitador social, fomentador de ideias, professor vocacionado, historiador original, homem de letras e, nessa qualidade, cultor exímio da língua pátria, e que sei mais. A opinião era absurda, até revoltantemente absurda, o erro de auto-apreciação monumental, e só a doença que o minava, a profunda depressão psíquica que o invadira, tão contrastante com o ânimo de prosélito que sempre lhe havíamos conhecido e de exemplo nos tinha servido, explicava juízo a seu próprio respeito tão oposto ao que dele fazíamos, nós, os seus amigos e discípulos ou simples admiradores, e tão radicalmente divergente do que dele já 


\section{Antonio Sérgio}

hoje fazem e amanhã continuarão a fazer os historiadores lúcidos e honestos da cultura portuguesa. Com semelhante juízo, por isto mesmo, nunca poderia eu estar de acordo e era com convicta energia que o tentava rebater, sem êxito aliás, face ao entendimento desalentador que ele dava da sua própria obra e tão profundamente se enraizara no seu espírito.

Errada era, igualmente, como não podia deixar de ser, a apreciação relativa que ele então fazia dessa obra multiforme, ao conceder primazia à sua acção de cooperativista e cooperador, acção em que tantos de nós, incapazes de o acompanhar nos seus voos de pensador cimeiro, nos haviamos sentido aptos a imitá-lo. Mas, apesar de tudo, não deixava de ser reconfortante, numa hora em que a alma já esmorecera e a morte se aproximava, mostrando-se-nos descrédulo de si próprio um homem que só conhecêramos altivo e lutador, não deixava de ser reconfortante, repito, verificar que ele sentia que não deixaria a vida sem a convicção de que legara ao seu povo algo de válido e exaltante; por isso, só por isso, deixo aqui esta nota de recordação muito pessoal.

A Constituição de 1976, em dispositivos que não foram atingidos pela revisão que recentemente sofreu, nem tão-pouco melhorados como deveriam e facilmente poderiam ter sido, deixou criado legalmente entre nós o "sector cooperativo», abrindo as portas ao aperfeiçoamento do apoio oficial a um movimento popular bem espontâneo, antigo em Portugal, tutelado de perto mas não aniquilado pelo corporativismo, e que revivera com natural e impetuosa espontaneidade logo após a Revolução e nos primeiros tempos desta. Por outro lado, em obediência à orientação adversa à tutela estatal, orientação que Sérgio sempre defendeu, preocupado como estava em preservar a autonomia do movimento cooperativo perante o poder político, tive eu próprio a grata oportunidade, quando passei discretamente pelo Governo, sem abdicar da minha adesão ao ideal cooperativista, de criar o "Instituto António Sérgio do Sector Cooperativo», organismo governamental em cujo "Conselho Coordenador», em paridade com representantes dos Ministérios, as cooperativas estão representadas, através das respectivas Uniões ou Federações. Prestou o Instituto António Sérgio, penso eu, úteis serviços ao cooperativismo português, sem nele procurar intervir nem interferir, sob a presidência de um companheiro estimado de Sérgio, seu colaborador em variadas iniciativas cooperativistas e cooperadoras, Fernando Ferreira da Costa, actualmente posto à margem. Por outro lado ainda, embora nos vejamos forçados a reconhecer que o ímpeto popular pró-cooperaçã̃o, 


\section{Utopia Sergiana}

a que aludi há pouco, abrandou bastante, o certo é que existe hoje entre nós e se mantem actuante, um «sector cooperativo», não tão vigoroso e expandido como nós outros, os cooperativistas, de ontem e de hoje, desejaríamos, nem tão bem articulado internamente como lhe conviria e ao País, mas de qualquer forma um sector distinto, com dignidade constitucional reconhecida, apto a desenvolver-se muito mais do que já está quando as condições políticas voltarem a ser estimuladoras em vez de inibidoras como são no momento em que escrevo. Sobre ele paire, para todo o sempre viva, a sombra tutelar de António Sérgio!

Deixemos, porém, o tema do cooperativismo que, por me apaixonar tanto como a Sérgio, me julgaria capaz de desenvolver bem mais extensamente, para passar a tratar da última das três utopias sergianas, que são a matéria deste breve estudo.

Foi certamente uma utopia que se prolongou tanto no tempo que acabou por se revestir de certo carácter mítico, dito isto sem querer insinuar que não fosse tão digna de respeito intelectual e moral como o são as outras a que me referi.

António Sérgio, apesar de ter sido Ministro num breve mas corajoso e imaginoso Governo presidido por Álvaro de Castro, a que também pertenceu Mário de Azevedo Gomes, nunca fora apoiante sem reservas nem defensor incondicional da República instaurada em 1910 e derrubada em 1926, antes a criticava frequentemente com severidade, e se lhe opunha muitas vezes pugnazmente, pelo que pensava ter ela, ao mesmo tempo, de falta de idealismo e ausência de realismo: falta de idealismo nas grandes concepções inspiradoras de uma política nacional genuinamente democrática, educadora de cidadãos, renovadora de mentalidades; ausência de realismo na acção quotidiana dos Parlamentos, dos Governos, dos Partidos, dos políticos profissionais em suma, acção por ele tantas vezes classificada como mesquinha, oportunista e sem horizontes. Sempre que se referia publicamente à política e à generalidade dos políticos da época, sobretudo depois de integrado no grupo particularmente crítico e inexoravelmente moralizador Seam Nova, era com dura sinceridade que o fazia, era com austero rigor que vaticinava os perigos a que a República, mal governada (pensava ele, muitas vezes, embora nem sempre, com razão) permanentemente estava sujeita de sucumbir aos golpes de inimigos que, ora dominados 


\section{António Sérgio}

por ideologias obsoletas senão arcaicas, ora ao serviço de interesses plutocráticos de grupos privilegiados, jamais a haviam tolerado e incessantemente se movimentavam para a derrubar pela força das armas.

Não obstante, logo que certos militares, na sua grande maioria tenentes e capitães, influenciados pela propaganda do Integralismo Lusitano, hábil e persuasivamente realizada por alguns escritores talentosos, contra a qual só se levantara eficazmente a grande voz de Raúl Proença, conseguiram dar o golpe vitorioso do 28 de Maio de 1926, com a participação de alguns oficiais republicanos despeitados ou iludidos, perante o entusiasmo de poucos, a perplexidade de muitos e a passividade de quase todos, logo António Sérgio, sem hesitar, tomou o seu lugar nas fileiras dos republicanos vencidos, esquecendo divergências e porventura até ofensas, se levantou contra a ditadura e em defesa das liberdades públicas que imediatamente começaram a ser cerceadas e, desde a primeira hora, o fez com ânimo de intransigência perante a reacção cuja vitória próxima estava à vista. Dele podemos dizer, como evidentemente de muitos outros, intelectuais ou simples homens do povo, que foi «um resistente da primeira hora». Mas foi principalmente depois que os militares, feita a prova da sua incompetência administrativa e financeira, deliberaram franquear a Salazar as portas da governação, desde logo com mãos livres para agir como melhor lhe parecesse, que Sérgio mais se rebelou contra o novo regime e mais tentou, sob os limites da censura, que se ia apertando, combater ideologicamente o maurrassiano Estado Novo que o discurso de Salazar na «Sala de Risco», revelador da aceitação das teses integralistas, deixara delineado, que os «constituintes» do princípio dos anos trinta configuraram juridicamente no segredo dos gabinetes e que o povo pseudo-plesbicitou na farsa eleitoral de 1933, precursora de várias outras que se lhe seguiriam.

António Sérgio abominava intelectualmente António de Oliveira Salazar, ele que ambicionava convencer pela educação, pela cooperação e pela persuasão, este que sempre se propôs friamente dominar pela intriga, a mentira, a corrupção e a força. Nem um nem outro, presumo eu, devem ter apreciado um elogio comparativo simultâneo que, em hora infeliz, Gilberto Freyre se lembrou de fazer dos «dois Antónios»), já que nenhuma outra similitude, salvo esta do nome próprio, entre eles existia, e a não ser talvez também a de se apresentarem ambos publicamente como humildes, quanto tanto um como o outro eram orgulhosos e seguros da excepcionalidade do seu valor. Por isso, assumido o poder pelo 


\section{Utopia Sergiana}

homem forte, gélido e astuto importado de Coimbra, e estabelecido nas leis e nas instituições o "corporativismo», fruste versão portuguesa do fascismo italiano, a luta política de Sérgio contra o regime não parou e só esmorecia quando as circunstâncias eram por demais impeditivas da expressão do pensamento. Não acreditando que o sistema se liberalizasse a ponto de procurar um dia sucessor por uma via eleitoral honesta, isto apesar do ardor que pôs em certa ocasião na malograda «campanha de promoção do voto», o pensador teorizante tornou-se activo conspirador quotidiano e passou a interessar-se pela procura de uma solução de índole militar. Sabia ele, talvez até por ter sido oficial de marinha, que os oficiais democratas eram numerosos, mesmo depois das depurações (muitas delas violentas) impostas pelo regime, que a muitos deles repugnava a ideia de verem a corporação a que pertenciam suporte e garante de um governo que se ufanava do seu anti-democratismo (só mais tarde, ganha a guerra pelos aliados, surgiria a ideia hipócrita de aceitar nominalmente a democracia, crismando-a porém de orgânica), e que não escasseavam, nas forças armadas, elementos dispostos em princípio a pegar em armas contra a infindável ditadura. Não saberia, porém, pelo menos tão claramente como conviria, que se tornava fácil ao poder manter afastados de situações de comando efectivo ou influência real os militares democratas profissionalmente prestigiosos, razão pela qual não conseguia contactar os interlocutores mais válidos e se via enredado em vagas conspirações, pseudo-conjuras e conversas inconclusivas com generais e oficiais superiores que lhe pareciam capazes de e dispostos a tomar as iniciativas que se impunham, quando afinal geralmente não o eram. As desilusões sucediam-se, as tentativas fracassavam, os insucessos acumulavam-se, as conspirações abortavam, os revolucionários potenciais sumiam-se e alguns traíam, mas ele, o filósofo tornado militante, sempre sereno e sem ignorar os riscos pessoais a que estava sujeito, não desistia de procurar contactos, estabelecer ligações, suscitar adesões, incitar possíveis combatentes.

Quem um dia fizer a história meticulosa da resistência militar ao regime, com as suas muitas conjuras e raras sublevações, comprovadora de que as forças armadas nunca estiveram coesas na defesa deste, há-de certamente deparar a cada passo com a figura «intrometida» do civil António Sérgio, mas não serei eu, que não sou historiador, quem se proporá efectuar semelhante investigação, nem sequer deixá-la esboçada. Referirei, porém, dois factos, o primeiro importante e de todos conhecido, o segundo irrelevante e só de mim sabido, mas 
que relatarei por o considerar curiosamente revelador deste vector que estou agora considerando da utopia sergiana.

$\mathrm{O}$ primeiro, bem conhecido como disse e várias vezes descrito, é que foi Sérgio quem, após com ele se ter relacionado para finalidades conspiratórias, lançou o nome de Humberto Delgado como candidato oposicionista apto a ganhar as eleições presidenciais de 1958, um dos que mais intensamente lutou pela aceitação desta candidatura por todas as forças oposicionistas, um dos que mais se empenhou na ingrata campanha em que o "general sem medo» se envolveu e veio a conduzir, anos depois, à ignóbil tragédia que os portugueses nunca deveriam esquecer. Aqui, a utopia de Sérgio foi só uma e quantos de nós dela compartilhámos com igual credulidade: a de que o ditador, apesar dos seus péssimos antecedentes, designadamente no que se refere ao procedimento para com o M.U.D em 1947-48, iria aceitar honestamente o repto que lhe era feito e os resultados deste. Utopia funesta nos seus resultados imediatos e próximos, mas também utopia fecunda porque a campanha destemida do general Delgado revelou, interna e externamente, a fraqueza ingénita de um regime aparentemente forte (já então condenado a lançar-se irreflectidamente na nefasta aventura da guerra colonial), porque desencadeou acções futuras que ajudaram a corroer o sistema por dentro, porque contribuiu para manter viva a esperança de que a liberdade acabaria por chegar a Portugal, porque induziu inúmeros militares, até então passivos, a reconhecer que se ia tornando cada vez mais impossível às forças armadas consentir que se prolongasse por mais tempo uma situação já condenada pela marcha implacável a caminho do futuro.

O segundo facto, em si mesmo irrelevante como já reconheci, mas que resolvo agora tornar público, por o achar sintomático da sistemática sergiana tendência para a utopia, foi o que passo a relatar, pedindo desculpas por ter que falar tanto a meu próprio respeito, e solicitando que lhe reconheçam o carácter memorialista que pretendo atribuir-lhe, e que talvez não destoe muito numa Revista de História.

Em 1945, tendo concorrido ao lugar de professor catedrático do Instituto Superior de Agronomia, e não tendo aparecido outros concorrentes, deliberou o Conselho Escolar, por unanimidade, nos termos da lei então em vigor, propor ao Ministro da Educação o meu provimento por convite, proposta que obteve então rápido despacho favorável (estava-se no fim da guerra, na iminência da vitória das democracias), razão pela qual fui nomeado professor catedrático pelo prazo de dois anos; esta era, com efeito, a duração para o exercício 


\section{Utopia Sergiana}

de funções dos nomeados por convite, entendendo-se que a eventual reiteração da proposta decorrido aquele tempo de exercício da docência equivalia a tê-lo o Conselho Escolar considerado equivalente à prestação das provas públicas. Quando chegou a altura de ser necessário votar a minha recondução, Maio 1947, encontrava-se o Ministro da Educação da época, cujo nome não me interessa recordar, empenhado em «sanear» as Universidades, o mais intensamente que pudesse, dos professores não afectos ao regime, o que era notoriamente o meu caso. A proposta do Conselho Escolar, de novo votada por unanimidade, seguiu para o Ministério, juntamente com uma análoga relativa ao meu colega e hoje saudoso amigo Prof. Branquinho d'Qliveira, e pouco tardou para que chegassem ao Instituto rumores insistentes de que o tal Ministro, que já então demitira numerosos professores, por sinal todos altamente qualificados cientificamente (basta lembrar os nomes ilustres de Fernando Fonseca, Pulido Valente e Ferreira de Macedo), recusaria a homologação proposta.

Recebi então conselhos insistentes de leais amigos, entre eles o do Prof. Azevedo Gomes, entretanto já demitido também ao mesmo tempo que Bento de Jesus Caraça, no sentido de evitar durante algum tempo quaisquer tomadas de posição de cariz político que oferecessem ao Ministro mais pretextos para despachar negativamente a proposta em seu poder (o que ele, meses depois, veio efectivamente a fazer, com o fundamento de que Branquinho d'Oliveira e eu não havíamos dado «garantias de colaborar na realização dos fins superiores do Estado»)!). Segui o conselho sem dificuldade, não só porque as minhas anteriores intervenções haviam sido apenas eventuais mas também porque, naquela precisa ocasião, não estavam à vista razões que me forçassem moralmente a proferir publicamente afirmações políticas. Durante este compasso de espera, Sérgio publicou a sua tão bela «Alocução aos socialistas», texto que bem mereceria ser mais lembrado do que está, em especial pelos que são ou se dizem socialistas. Nela, incidentalmente, em nota de pé de página, mas com generosidade extrema, em termos de penhorante amizade, fez uma referência à minha pessoa. Fiquei gratíssimo, honrado como nunca até então me sentira e talvez como não voltarei a sentir-me, mas confesso não ter podido refrear o pensamento egoísta de que, face à particular conjuntura acima descrita, a ocasião não teria sido a mais aconselhável para se falar de mim, publicamente, na qualidade de democrata e socialista. Mencionei o caso ao Prof. Azevedo Gomes, de nenhum modo em tom de queixa ou protesto, apenas casualmente, como amigos que éramos, mas sem lhe esconder a minha preo- 


\section{Antonio Sérgio}

cupação, que ele imediatamente partilhou, sem que a conversa fosse mais por diante.

Passados alguns dias, com viva surpresa, porque ele nunca estivera em minha casa, recebi a visita de António Sérgio, a quem Azevedo Gomes dera conta do encontro comigo. Apareceu pesaroso, apresentou desculpas tão veementes que me deixaram embaraçado, afirmou que, independentemente da minha conveniência pessoal, era sua opinião que a continuidade da minha presença na Universidade apresentava valor para a causa da Democracia e que, por isso mesmo, lamentar-se-ia sempre se, acaso, as suas palavras viessem a influenciar a minha não-recondução. Como eu procurasse sossegá-lo, afirmando-lhe, em primeiro lugar, que o Ministro já certamente havia decidido não me nomear e que não me faltariam oportunidades profissionais de ganhar a minha vida, quer no país quer no estrangeiro (como, efectivamente, veio a acontecer, no Brasil) interrompeu-me vivamente, desta vez com semblante jubiloso e até com certo ar triunfalista, para me dar a conhecer, obviamente a título confidencial, que não havia motivos para eu me sentir apreensivo porque.... «isto estava por pouco, talvez até por dias!». Perante a minha incompreensão, informou-me que eclodiria em breve uma sedição militar à testa da qual se encontrava o major (na reserva) Jorge Botelho Moniz, até então considerado um dos mais sólidos apoiantes militares de Salazar e homem de confiança deste (lembro-me até de Sérgio o ter apelidado de "condestável do regime!»); o movimento em causa encontrava-se, desta vez, de tal modo bem preparado que Salazar nem o poderia impedir nem vencer. Consequentemente, as referências que ele, Sérgio, me fizera na sua "Alocução» em nada iriam comprometer a minha carreira docente, antes poderiam incentivá-la, como era aliás seu desejo. Sempre surpreendido com tanta candura (porque, desta vez, me parecia que se tratava mesmo de candura), conquanto sem deixar de me mostrar grato pela prova de confiança que acabara de receber, tentei mostrar-lhe que as suas informações não se ajustavam a outras que me haviam chegado, e revelavam hesitações entre os conspiradores e mesmo muita descoordenação na conjura, e que, por outro lado, Jorge Botelho Moniz, por muito inteligente que fosse e brilhante militar, era homem com um claro passado reaccionário: vencedor do general Sousa Dias na Ilha da Madeira, combatente contra outras revoltas republicanas, lutador enérgico na guerra civil de Espanha ao lado dos franquistas (aos quais prestou, nos primeiros dias do levantamento contra a República espanhola, inestimáveis serviços através das falsas notícias emitidas pelo seu Rádio-Clube Por- 


\section{Utopia Sergiana}

tuguês), homem influente na Legião Portuguesa, e outros similares atributos; afigurava-se-me, em suma, ser ele, J. B. M., a última pessoa em quem se deveria confiar para... restaurar a Democracia. Sem que, evidentemente, contestasse as minhas acusações ao caudilho que nos propunha, nem procurasse defender o negro passado político deste, Sérgio manteve a sua convicção de que Botelho Moniz agiria em breve, que possuía força bastante para expulsar Salazar do poder e que... depois se veria. Retirou-se em atitude confiante, numa posição física que bem lhe conhecíamos, com a cabeça bem erguida, porém sem jeito de arrogância, e o olhar firme. Eu, porém, porque não confessá-lo?, fiquei perplexo, senão mesmo desanimado e, esquecendo de todo o meu problema pessoal, senti desvanecerem-se as fracas esperanças que ainda conservaria de ver o nosso infortúnio político aliviado pela intervenção de militares de elevada patente.

Sérgio, numa palavra, continuava a dar a sua confiança a quem não a merecia, a acreditar que generais e oficiais superiores, colaboradores ostensivos ou não do Estado Novo, estariam dispostos a seguir o exemplo raro de Humberto Delgado e a trabalhar para restabelecer a República democrática. Esquecia-se assim que não haviam sido altas patentes militares quem depusera a Monarquia, nem quem preparara o 28 de Maio de 1926, como não haveriam de ser, muitos anos depois, já então o escritor há muito falecera, quem abateria a cega e obstinada ditadura. Como tem acontecido com todas as ditaduras que conseguem ganhar tempo para criar uma polícia secreta forte, uma guarda pretoriana bem armada e obediente e uma censura severa, generalizada e vigilante, ao mesmo tempo que vão defendendo de infiltrações as forças armadas tradicionais e contendo as aspirações da juventude, só a aventura militar externa consegue trazer um desenlace à situação de imobilismo assim criada e abrir os olhos da instituição armada para que ela entenda que as situações se transformaram, os horizontes mudaram e se lhes tornou impossível, sem descrédito total, manter o seu apoio a ditadores e ditaduras sem prestígio nem apoio popular.

No caso português, obcecados como quase todos nos encontrávamos, incluindo a maioria dos democratas (sejamos sinceros!), pela ideia de que as Colónias eram outras tantas províncias de um imaginário Portugal «multi-racial» e «pluri-continental», as guerras a que a insurreição dos seus povos nos forçavam afiguravam-se-nos meras guerras civis internas e não aquilo que verdadeiramente eram: guerras externas travadas para conquistar a independência de nações que nós dominávamos. Este conceito, suponho eu, ao longo da vida mi- 


\section{Antonio Sérgio}

litante de Sérgio, ainda não teria amadurecido o suficiente para o escritor lhe ter dado a sua atenção. Certos, porém, poderemos todos estar de que, tivesse ele vivido o suficiente para ver exibida à luz do dia a face negativa do colonialismo português, altruísta como era, voltado contra todas as opresr sões e imune aos apelos do nacionalismo (que nunca confundiu com o patriotismo) teria chegado, antes de muitos outros, à conclusão de que conceder aos povos das Colónias a liberdade que justamente reclamavam equivalia a conseguir, por uma via até então não trilhada, aquilo que afinal ele sempre exigira: a democratização do seu próprio país.

António Sérgio a todos nós que o conhecemos e lemos ensinou a exercer permanentemente o espírito crítico, e foi num esforço para seguir a sua austera lição que redigi estas linhas.

Destinam-se elas a honrar, na medida das minhas limitadas capacidades, essa imensa e honrada figura de grande português «cidadão do mundo», de intelectual incapaz de se acomodar à estupidez, à pusilanimidade e à insídia. Se os leitores assim a não interpretarem, desde já reconheço ter errado o meu alvo. 